\title{
Annual biologic treatment cost for new and existing patients with moderate to severe plaque psoriasis in Greece [Corrigendum]
}

\author{
Fragoulakis V, Raptis E, Vitsou E, Maniadakis N. Annual \\ biologic treatment cost for new and existing patients with \\ moderate to severe plaque psoriasis in Greece. Clinicoecon \\ Outcomes Res. 2015;7:73-83.
}

The authors apologize that the following errors appear in their paper:

- Page 75 , right column, line 29 , citation ${ }^{39}$ should be ${ }^{38}$

- Page 76 , left column, line 30 , citations ${ }^{40,41}$ should be ${ }^{39,40}$

- Page 76 , left column, line 32 , citation ${ }^{42}$ should be ${ }^{41}$

- Page 76, left column, line 40 , citation ${ }^{43}$ should be ${ }^{42}$

- Page 76, right column, line 12 , citations ${ }^{2,44}{ }^{46}$ should be be $^{2,43}$

- Page 78 , left column, line 38 , citation ${ }^{47}$ should be ${ }^{46}$

- Page 78 , right column, line 3, citations ${ }^{15,48-52}$ should be ${ }^{15,47-51}$

- Page 78 , right column, line 9 , citation ${ }^{53}$ should be ${ }^{52}$

- Page 78 , right column, line 18 , citation ${ }^{54}$ should be ${ }^{53}$

- Page 78 , right column, line 21 , citation ${ }^{55}$ should be ${ }^{63}$

- Page 79, left column, line 31, citations ${ }^{56-60}$ should be ${ }^{54-59}$

- Page 79, left column, line 35, citations ${ }^{51,61-63}$ should be ${ }^{50,60-62}$

\section{Publish your work in this journal}

ClinicoEconomics \& Outcomes Research is an international, peerreviewed open-access journal focusing on Health Technology Assessment, Pharmacoeconomics and Outcomes Research in the areas of diagnosis, medical devices, and clinical, surgical and pharmacological intervention. The economic impact of health policy and health systems organization also constitute important areas of coverage. The manuscript management system is completely online and includes a very quick and fair peer-review system, which is all easy to use. Visit http://www.dovepress.com/testimonials.php to read real quotes from published authors. 